\title{
Renal fate of circulating advanced glycated end products (AGE): evidence for reabsorption and catabolism of AGE-peptides by renal proximal tubular cells
}

\author{
A. Guglincci, M. Bendayan \\ Department of Anatorny, University of Montreal, Montreal, Quebec, Canada
}

\begin{abstract}
Summary The presence of excessive amounts of advanced glycation end products (AGE) in tissues or in the circulation may critically affect the progression of diabetic nephropathy. Circulating AGE levels, mainly in the form of small peptides, increase in diabetic patients or in patients with end-stage renal disease. This rise correlates with the severity of the nephropathy. However, so far little is known about the fate of AGE-proteins and AGE-peptides in renal tissue, and in order to elucidate this issue we undertook the present study. AGE-bovine serum albumin (AGE-BSA) and AGE-peptides were prepared, characterized by spectrophotometry, spectrofluorometry, chromatography and SDS-PAGE. AGE-peptides reacted in vitro with LDL producing biochemical and ultrastructural modifications. Using colloidal gold post-embedding immunoelectron microscopy with an anti-AGE antibody generated in our laboratory, we followed, in a short-term kinetic study, the cellular and sub-cellular localisation of circulating AGE-products throughout the nephron. AGE-peptides or AGE-BSA were injected into otherwise normal rats and detected by protein A-gold immunocytochemistry after 15,30 or 45 min of circulation.
\end{abstract}

Most of the AGE-BSA was found in the lumen of capillary vessels and distributed along the endothelial side of the glomerular basement membrane. Presence on mesangial matrix was also apparent. AGEpeptides were easily filtered and actively reabsorbed by the proximal convoluted tubule. At $15 \mathrm{~min}$, little labelling was found in the glomerular wall. Instead, the labelling was present in the urinary space and microvilli of epithelial cells. Early endosomes displayed intense labelling as well. At $45 \mathrm{~min}$, late endosomes and lysosomes added to the pattern of labelling. The distal tubule epithelial cells were devoid of labelling for any of the intervals studied. AGE-peptides but not AGE-BSA could be detected in the urine of injected rats. These observations point to participation of the endo-lysosomal apparatus of the proximal convoluted tubule to the disposal of AGE-peptides, while giving an ultrastructural support for a key role of the kidney in AGE catabolism. [Diabetologia (1996) 39: 149-160]

Key words Diabetes mellitus, glycation, colloidal gold cytochemistry, glomerulosclerosis, LDL, clearance.
Received: 9 May 1995 and in revised form: 20 July 1995

Corresponding author: Dr. M. Bendayan, Department of Anatomy, Université de Montréal, C.P. 6128, Succ, CentreVille, Montréal, Québec, H3C 3J7, Canada

Abbreviations: AGE, Advanced glycation end products; BSA, bovine serum albumin; BHT, butylated hydroxytoluene; DEAE, diethyl aminoethyl cellulose; GBM, glomerular basement membrane; PBS, phosphate buffered saline; PMSF, phenylmethylsulphonyl fluoride; TBS, Tris buffered saline.
The long-suspected but controversial issue of hyperglycaemia being a key step towards diabetic chronic complications is now resolved [1]. The recent publication of the Diabetes Control and Complications Trial (DCCT) unequivocally demonstrates the prevention of complications by good glycaemic control in insulin-dependent diabetic (IDDM) patients $[2,3]$. One of the mechanisms by which sustained hyperglycaemia has an effect, is glycation and its ultimate consequence, advanced glycation [4-8]. Accelerated modification of proteins by advanced glycation is involved 
in the pathogenesis of nephropathy, macro- and microangiopathy, and cataracts in diabetic patients $[6$, 9-11]. Advanced glycation end products (AGE) are produced in proteins as a consequence of the non-enzymatic formation of adducts between these molecules and reducing sugars. In this reaction, sugars react non-enzymatically with a wide range of proteins to form early glycation (Amadori) products. On long-lived proteins, a complex series of rearrangements and oxidative reactions follows leading to the formation of multiple, very reactive species collectively called AGE products. AGE products accumulate in vivo on vascular wall collagen and basement membranes as a function of age and levels of glycaemia $[8,12-18]$. They are capable of producing crosslinking of proteins and have been shown to display diverse biological activities including increased endothelial cell permeability [19-21], binding to receptors on macrophages, endothelial and mesangial cells [19, 22-26], activation of macrophages with secretion of cytokines following AGE-ligand-receptor interaction [25-28], quenching of nitric oxide with the consequent inhibition of vascular dilatation [12], enhancing oxidative stress $[21,29,30]$ and oxidation of LDL [31]. In fact, a growing body of evidence points to a causal relationship between AGE accumulation and the development of chronic diabetic complications. Diabetic nephropathy, leading to glomerulosclerosis, is one complication, and is responsible for kidney failure in $30-40 \%$ of diabetic patients [32]. The development of new assays for AGE-products has shown that they not only accumulate in tissues but circulate as well [31, 33-37]. Particularly impressive are data showing a dramatic increase in the levels of circulating AGE-peptides in diabetic end-stage renal disease that correlate with the severity of the nephropathy $[15,34,36]$. Short-term administration of exogenous AGE-modified albumin to otherwise normal rats and rabbits leads to the covalent attachment of these adducts to the extracellular matrix in several tissues [16]. Moreover, following this modification, a range of vascular dysfunctions, resembling those observed in diabetes, occurs.

We have recently shown that AGE-bovine serum albumin (AGE-BSA) probes tagged with colloidal gold display great reactivity towards glomerular structures [38]. Similarly, chronic injections of AGEBSA but not of BSA alone, produce the classical picture of diabetic glomerulopathy in otherwise euglycaemic animals [39]. It is apparent from these and other studies that small metabolic fragments of AGE proteins are implicated in these phenomena. In fact, it is this low molecular weight AGE-peptide fraction that accumulates preferentially in the blood of diabetic and uraemic patients, representing up to $80 \%$ of AGE plasma immunoreactivity $[15,18,32-$ $34,36,40,41]$. Up to five times higher levels of AGE were demonstrated in diabetic patients undergoing haemodialysis as compared with euglycaemic subjects $[15,18,34]$. Circulating AGE-peptides are not easily removed by dialysis and some authors even suggest that they might be potential candidates for the "uraemic toxins" or "middle molecules" involved in complications related to dialysis $[18,33]$. Kidney failure itself also leads to a dramatic accumulation of AGE even in the absence of diabetes [32].

In this regard, it is certain that the kidney plays an important role in the clearance of circulating AGE from the bloodstream. However, so far, little is known about the fate of AGE proteins and AGEpeptides in kidney tissue. In order to obtain further insight on this issue, we undertook the present study. AGE-BSA and AGE-peptides were prepared and injected into otherwise normal rats. Using immunoelectron microscopy with a newly generated anti-AGE antibody, we followed, in a short-term kinetic study, the cellular and subcellular localisation of circulating AGE throughout the nephron.

\section{Materials and methods}

Preparation and characterisation of BSA containing $A G E$. Crystallised and lyophilised BSA, fraction V (Sigma Chemicals, St. Louis, Mo., USA) was glycated in vitro by incubation at $37^{\circ} \mathrm{C}$ for 120 days in the presence of $1 \mathrm{~mol} / 1$ glucose in $0.5 \mathrm{~mol} / 1 \mathrm{so}-$ dium phosphate buffer containing $1 \mathrm{mmol} / \mathrm{l}$ EDTA, $1 \mathrm{mmol} / 1$ phenylmethylsulphonyl fluoride (PMSF), $1 \mathrm{mmol} / 1$ aprotinin and $1 \mathrm{mmol} / 1$ sodium azide. Protein concentration was $100 \mathrm{mg} /$ $\mathrm{ml}$ and incubation was performed after sterilising the solution by passage through a $0.2-\mu \mathrm{m}$ Millipore membrane (Millipore Canada Ltd, Mississauga, Ont., Canada). Presence of AGE in our probes was confirmed by fluorospectrophotometry using excitation at $370 \mathrm{~nm}$ and emission at $440 \mathrm{~nm}$ for total fluorescence $A G E$ and excitation at 335 and emission at $385 \mathrm{~nm}$ for pentosidine-like fluorescence as previously described [42-44]. A Turner 430 spectrofluorometer (AMSCO Instruments, Carpinteria, Calif., USA) was employed for these measurements. Briefly, samples were adjusted to the same protein concentration $(1 \mathrm{mg} / \mathrm{ml})$ and an arbitrary value of 1 was assigned to fluorescence of control BSA. The fluorescence of modified BSA was reported to this reference value. The second criterion employed to measure AGE in BSA was their characteristic absorption spectrum [44] measured with a Shimadzu UV 160 U recording spectrophotometer (RPI Instruments Inc., Montreal, Quebec, Canada). Absorbance at $350 \mathrm{~nm}$ was reported to absorbance at $280 \mathrm{~nm}$ in order to correct for protein concentration [16].

Degree of modification of lysine residues was monitored by the trinitrobenzene sulphonic acid assay as previously described [45]. Briefly, $50-\mu l$ samples $(1 \mathrm{mg} / \mathrm{ml})$ were incubated with $1 \mathrm{ml} 0.48 \mathrm{mmol} / 1 \mathrm{NaHCO}_{3}$ and $50 \mu \mathrm{l} 3.3 \mathrm{ml} / 1$ trinitrobenzene sulphonic acid for $1 \mathrm{~h}$ at $37^{\circ} \mathrm{C}$. Absorbance at $340 \mathrm{~nm}$ of control (non-modified) samples was measured and free amines were calculated from a standard plot performed with valine. The AGE-BSA probes were also characterized by polyacrylamide gel electrophoresis in non-denaturing conditions (SDSPAGE). Electrophoresis was run according to the method of Lacmmli [46-48] on 7.5\% acrylamide gels. Equipment employed was Mini Gel from BioRad (Bio Rad Laboratories, Mississauga, Ont., Canada). Gels were stained with Coomassie Brilliant Blue. 
Preparation of AGE-peptides. AGE-peptides were prepared by proteolysis of AGE-BSA as previously described [31]. Briefly, $10 \mathrm{ml}$ of AGE-BSA (50 mg/ml in $10 \mathrm{mmol} / \mathrm{l}$ phosphate buffered saline (PBS), $\mathrm{pH} 7.4$ ) were incubated with $10 \mathrm{mg}$ of proteinase $\mathrm{K}$ for $20 \mathrm{~h}$ at $37^{\circ} \mathrm{C}$. Low molecular weight peptides $(<10 \mathrm{kDa})$ were then isolated by centrifugation of the digested material through a Centripep-10 membrane (Amicon) for $3 \mathrm{~h}$ at $4000 \times \mathrm{g}$. After $20 \mathrm{~h}$ proteolysis with proteinase $\mathrm{K}$, over $80 \%$ of AGE fluorescence was recovered in the less than 10 $\mathrm{kDa}$ fraction.

Determination of molecular weights of $A G E$-peptides. After separation by centrifugation of the digested AGE-BSA through a Centripep-10 membrane, $500 \mu \mathrm{l}$ of $5 \mathrm{mg} / \mathrm{ml} \mathrm{AGE-peptides}$ was applied onto a 40-cm Biogel P-6 gel filtration column (BioRad) equilibrated in $0.01 \mathrm{~mol} / \mathrm{l}$ sodium phosphate buffer containing $150 \mathrm{mmol} / \mathrm{l} \mathrm{NaCl}, 1 \mathrm{mmol} / \mathrm{l}$ EDTA, $1 \mathrm{mmol} / \mathrm{l}$ PMSF, $1 \mathrm{mmol} / \mathrm{l}$ sodium azide, $\mathrm{pH}$ 7.4. Chromatography was run at $10 \mathrm{ml} / \mathrm{min}$ flow rate using the same solution for elution. One-ml fractions were collected and read at $280 \mathrm{~nm}$ for proteins, at $350 \mathrm{~nm}$ for browning products, and fluorescence at $\mathrm{Ex}$ citation $370 \mathrm{~nm}$ and Emission $440 \mathrm{~nm}$. The void volume, estimated as the exclusion volume for haemoglobin, was $19 \mathrm{ml}$. The BioGel column was calibrated with insulin $\left(\mathrm{M}_{\mathrm{r}} 6000\right)$, bacitracin $\left(M_{r} 1400\right)$, riboflavin $\left(M_{r} 379\right)$ and glucose $\left(M_{r} 180\right)$.

Reaction of AGE-peptides with LDL. LDL ( $d=1.051-1.163$ $\mathrm{mg} / \mathrm{ml}$ ) was isolated from blood of healthy volunteers as described previously [49]. After dialysis LDL (1 mg/ml) was incubated at $37^{\circ} \mathrm{C}$ for different intervals up to $72 \mathrm{~h}$ in the presence or in the absence of $10 \mathrm{mg} / \mathrm{ml}$ AGE-peptides in $10 \mathrm{mmol} / \mathrm{l} \mathrm{so-}$ dium phosphate, $140 \mathrm{mmol} / / \mathrm{NaCl}, 1 \mathrm{mmol} / 1 \mathrm{EDTA}, 1 \mathrm{mmol} / \mathrm{l}$ PMSF, and $1 \mathrm{mmol} / \mathrm{l}$ sodium azide. LDL was subsequently dialysed and examined under electron microscope by negative staining [50], and by spectral analysis.

Antibodies. Anti-AGE antibodies were obtained by immunization of rabbits with AGE-BSA essentially as described previously $[34,51,52]$. Standard immunization protocols were followed [53]. Briefly two New Zealand white rabbits received four i.m. injections of a total of $350 \mu \mathrm{g}$ AGE-BSA emulsified with complete Freund's adjuvant. After 1 month the rabbits were subsequently given a booster of a half-dose of AGEBSA emulsified with incomplete Freund's adjuvant, and two similar boosters were repeated every month. Ten days after each booster the animals were bled and their antibody titres checked. After the third booster, the animals were bled, antiBSA antibodies were eliminated by adsorption of serum with BSA and an IgG fraction was prepared by ammonium sulphate precipitation and DEAE chromatography [54]. Specificity of the antibodies was checked by dot immuno blotting and double diffusion on agarose gels [54]. Advanced glycated $\mathrm{Hb}$ and $\operatorname{IgG}$ were prepared in a similar fashion as AGE-BSA. The three molecules as well as their non-glycated counterparts were employed to check the specificity of the antibody against AGE epitopes. Proteins were measured by the micro bicinconninic acid procedure [55] (Pierce, Chromatographic Specialties Inc, Brockville, Ont., Canada).

Circulation of exogenous $A G E-B S A$ and $A G E$-peptides. Sprague-Dawley male rats weighing $100 \mathrm{~g}$ were employed. The animals were anaesthetized with i.p. injections of urethane. Two animals were employed for each probe at each indicated time. AGE-peptides or AGE-BSA (10 mg/animal) were injected in the inferior vena cava. These probe concentrations were chosen since they had provided good signals in pilot studies without producing any major increase in proteinaemia and did not significantly affect the overall glomerular filtration process. After 15,30 or $45 \mathrm{~min}$ of circulation the animais were killed by terminal anaesthesia. The abdominal cavity was flooded with the fixative, $1 \%$ glutaraldehyde to begin fixation. Such a rapid fixation in situ allows for the retention of circulating proteins in the blood vessels and reduces extraction of extracellular circulating proteins during processing of the tissue samples for electron microscopy. Small pieces of kidney were excised and further fixed by immersion in $1 \%$ glutaraldehyde solution ( $0.1 \mathrm{~mol} / 1 \mathrm{phosphate}$ buffer) for $2 \mathrm{~h}$ at $4{ }^{\circ} \mathrm{C}$. The tissue fragments were then processed for electron microscopy by methanol dehydration and embedded in Lowicryl K4 M (IBEM Services, Inc, Saint Laurent, Québec, Canada) at $-20^{\circ} \mathrm{C}$ as previously described [56]. Thin sections were cut, mounted on nickel grids coated with Parlodion and carbon films and processed through the labelling experiments.

Detection of AGE-peptides in urine of injected rats. AGE-peptides were detected in urine samples by dot immunoblotting [47]. Briefly, 2- $\mu$ l aliquots were spotted onto nitrocellulose membranes and dried. Membranes were then blocked in $50 \mathrm{~g} /$ $1(\mathrm{w} / \mathrm{v})$ non-fat dry milk in Tris buffered saline (TBS) (10 mmol/1 Tris $\mathrm{HCl}, 257 \mathrm{mmol} / / \mathrm{NaCl}, \mathrm{pH} 7.5, \mathrm{TBS}$ ) for $2 \mathrm{~h}$, washed three times ( 5 min each) in TBS, and then incubated at room temperature overnight with the anti-AGE antibody diluted at 1:500 in non-fat dry milk. After three additional rinses in TBS containing $0.01 \%(\mathrm{w} / \mathrm{v})$ Tween 20 , blots were incubated with alkaline phosphatase-conjugated goat anti-rabbit IgG at 1:500 dilution in non-fat dry milk for $2 \mathrm{~h}$ before developing with a nitroblue tetrazolium substrate (Sigma).

Cytochemical studies. Tissue sections were incubated for $60 \mathrm{~min}$ on a drop of $10 \mathrm{~g} / \mathrm{l}$ glycine in $10 \mathrm{mmol} / \mathrm{l} \mathrm{PBS}$, pH 7.4. After washing in PBS the grids were transferred to a drop of $10 \mathrm{~g} / \mathrm{l}$ ovalbumin and incubated for $30 \mathrm{~min}$ at room temperature. Next, grids were incubated overnight at $4^{\circ} \mathrm{C}$ in a humidified chamber on a drop of the anti-AGE antibody. The grids were washed by three successive floatings on PBS while stirring, transferred to a drop of $10 \mathrm{~g} / \mathrm{l}$ ovalbumin and incubated for $30 \mathrm{~min}$ at room temperature. Next, the grids were incubated with 10 -nm protein A-gold complex for $30 \mathrm{~min}$ at room temperature [56]. Finally the grids were washed again by three successive floatings on PBS under stirring, then rinsed with distilled water and dried. Staining with uranyl acetate and lead citrate was performed before examination with a Philips 410 electron microscope (Saint Laurent, Québec, Canada).

Cytochemical controls. The specificity of the immunolabelling was assessed by several control experiments as described previously [56]: adsorption of the antibody by its specific antigen (AGE-BSA); use of protein A-gold alone and use of nonlabelled protein A-gold prior to the use of protein A-gold complex.

Morphometrical evaluation of the labelling. Distribution of AGE-BSA over the glomerular basement membrane (GBM) was performed by a quantitative evaluation of the labelling intensity and expressed as a ratio: distance endothelium-gold particle/distance endothelium-epithelium (resulting in values between 0 and 1) using a Carl Zeiss Videoplan electronic digitiser (Carl Zeiss Inc., Toronto, Ontario, Canada) as described previously [57]. For each animal, ten microscopic fields were recorded on video at $\times 31,000$ magnification and brought to a final magnification of $\times 105,000$. 
Table 1. Characterization of advanced glycated albumin (AGE-BSA)

\begin{tabular}{lllll}
\hline & $\begin{array}{l}\text { Free amines }^{\mathrm{a}} \\
(\mathrm{mmol} / \mathrm{l})\end{array}$ & $\begin{array}{l}\text { Fluorescence }^{b} \\
\text { (Arbitrary units) } \\
\text { Ex 370 nm/Em 440 nm }\end{array}$ & $\begin{array}{l}\text { Fluorescence }^{\mathrm{C}} \text { (arbitrary units) } \\
\text { Ex 350 nm/Em 385 nm }\end{array}$ & $\begin{array}{l}\text { Chromogen products }^{\mathrm{d}} \\
\text { A 350 nm/A 280 nm }\end{array}$ \\
\hline BSA & $0.86 \pm 0.03$ & $1.0 \pm 0.0$ & $1.0 \pm 0.0$ & 0.0 \\
AGE-BSA & $0.15 \pm 0.02$ & $42 \pm 0.5$ & $2.8 \pm 0.0$ & $0.56 \pm 0.1$ \\
\hline
\end{tabular}

Data represent mean \pm SD of two independent experiments run in duplicate. All the samples were adjusted to a protein concentration of $1.0 \mathrm{mg} / \mathrm{ml}$.

${ }^{a}$ Measured by the TNBSA reaction calibrated with a valine standard.

${ }^{b}$ Fluorescence was measured at excitation maximum of $370 \mathrm{~nm}$ and emission maximum of $440 \mathrm{~nm}$.

${ }^{c}$ Fluorescence was measured at excitation maximum of $335 \mathrm{~nm}$ and emission maximum of $385 \mathrm{~nm}$.

${ }^{d}$ Measured as absorbance at $350 \mathrm{~nm} / \mathrm{absorbance}$ at $280 \mathrm{~nm}$

\section{Results}

In this work we set out to study the renal fate of exogenously administered AGE. For that purpose we generated a probe, AGE-BSA by long-term incubation of BSA in the presence of high glucose and phosphate concentrations. This probe was used to prepare small peptides by proteolysis. Either AGEBSA or the resultant AGE-peptides were next injected into normal rats and their renal handling was followed by biochemistry and immunoelectron microscopy.

Biochemical characterisation of $A G E-B S A$ and $A G E$-peptides. The AGE-BSA probe was checked for late glycation products by characteristic fluorescence and by spectrophotometric spectra. The number of lysine residues modified was quantitated by the trinitrobenzene sulphonic acid assay reaction. Table 1 summarises the biochemical characterisation of the AGE-BSA probe used in this work. AGE-BSA contained AGE producing the characteristic fluorescence and absorption spectra. Over $80 \%$ of lysine residues in the AGE molecules have been modified as shown by direct measurement of still-reactive amino groups. As expected, extensive cross-linking of AGE-BSA was apparent from SDS-PAGE electrophoresis. On Figure 1 the band at $68 \mathrm{kDa}$ characteristic for BSA has been substituted by large molecular weight cross-linked molecules with $\mathrm{M}_{\mathrm{r}}$ over $200 \mathrm{kDa}$.

One part of AGE-BSA was next employed in the preparation of AGE-peptides. After ultrafiltration, AGE-peptides were further characterized by gel filtration chromatography. Figure 2 a shows the elution profile of AGE-peptides on a BioGel P6 column. Over $90 \%$ of AGE fluorescent products elute in peak I and display a $\mathrm{M}_{\mathrm{r}} 3 \mathrm{kDa}$ as calculated from the standard plot in $2 \mathrm{~b}$.

Reactivity of AGE-peptides towards $L D L$. To test in vitro the potential reactivity of our AGE-peptides we incubated them in the presence of LDL. In this way both binding to protein and lipids were assessed at the same time. AGE-peptides readily bind to

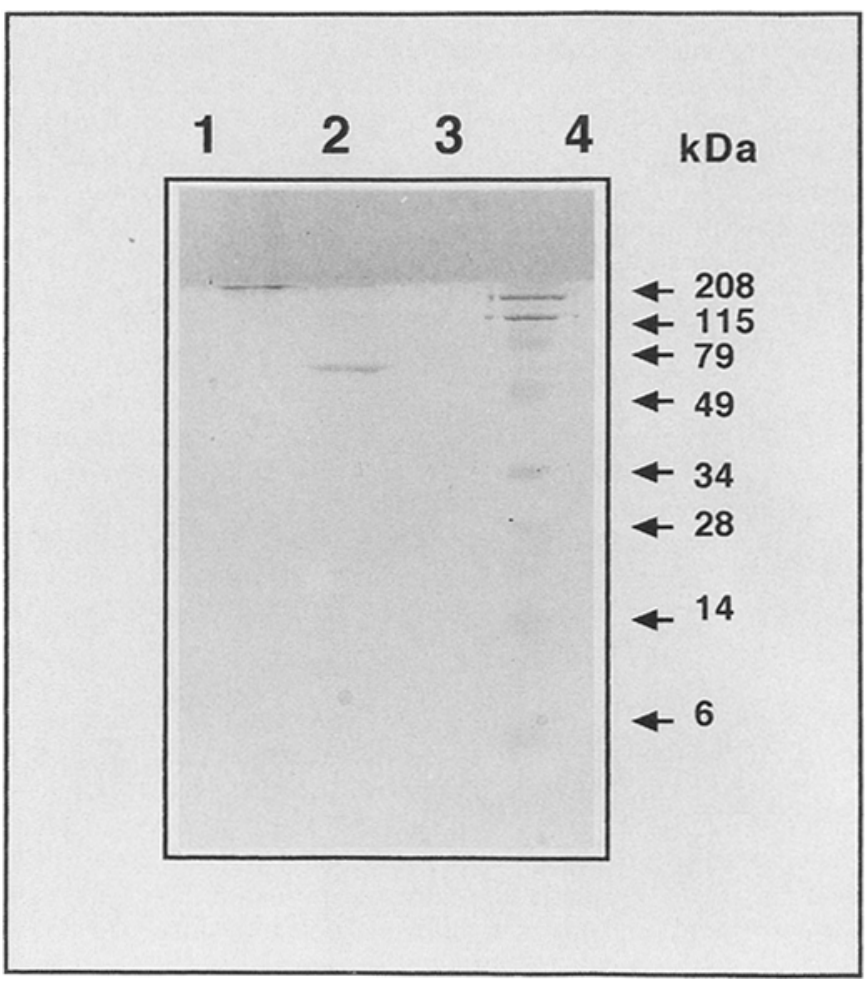

Fig. 1. SDS-PAGE of the AGE probes used in this study. AGE-BSA (line 1), BSA (line 2) and AGE-peptides (line 3) $(15 \mu \mathrm{g}$ each) were loaded onto a $7.5 \%$ polyacrylamide gel with a stacking gel of $4 \%$ polyacrylamide. Staining was performed with Coomassie Brilliant Blue. Line 4 contains molecular weight markers. Advanced glycation of BSA produced cross-linking of the molecule leading to the formation of high molecular weight adducts which scarcely enter the separation gel (line 1). Advanced glycated peptides produced by digestion of this AGE-BSA are not visible on the gel, which indicates that their $M_{r}$ is inferior to $6 \mathrm{kDa}$ (line 3 ) as judged by $M_{r}$ markers on line 4

LDL and produce drastic ultrastructural modifications. Even after only an overnight incubation in non-oxidative conditions (addition of EDTA, ascorbic acid and butylated hydroxytoluene) LDL showed major changes as illustrated in Figure $3 \mathrm{~b}$. Instead of the discrete 20-nm particles of LDL incubated in the absence of AGE (Fig. 3a), AGE-incubated LDL 

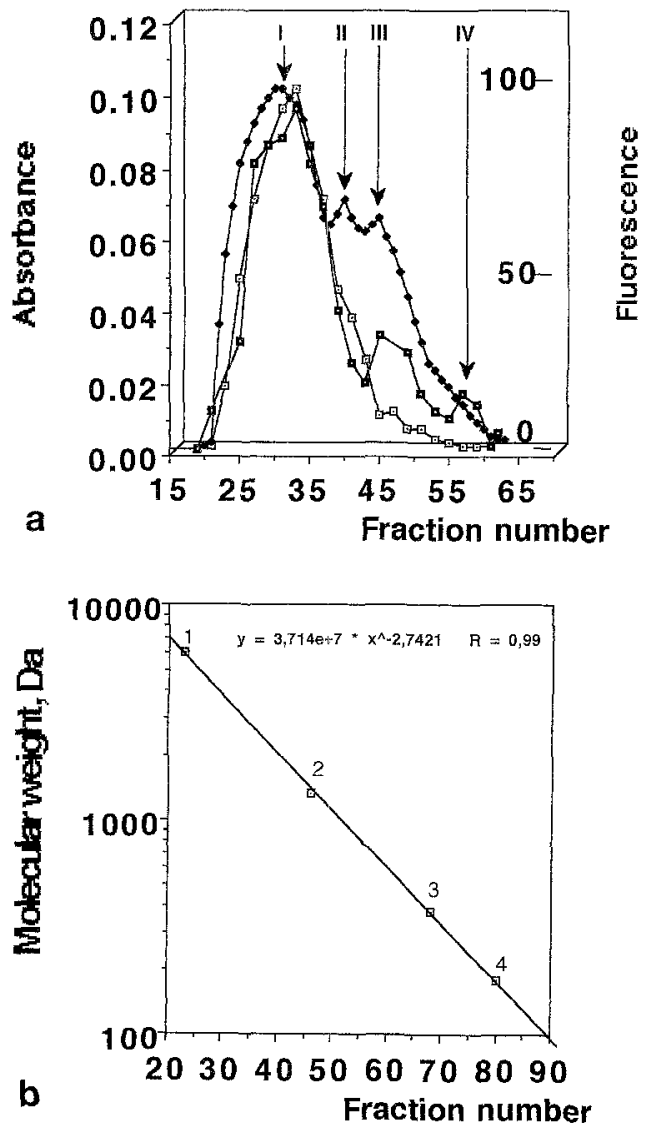

Fig. 2a, b. Molecular weight determination of AGE-peptides by exclusion-diffusion chromatography. a Elution profile of chromatography of AGE-peptides on a Biogel P6 column. AGE-peptides $(500 \mu \mathrm{l}$ of $5 \mathrm{mg} / \mathrm{ml})$ was applied onto a $40-\mathrm{cm}$ Biogel P-6 exclusion-diffusion column equilibrated in 0.01 mol/1 sodium phosphate buffer containing $150 \mathrm{mmol} / \mathrm{l} \mathrm{NaCl}$, $1 \mathrm{mmol} / \mathrm{l} \mathrm{EDTA}, 1 \mathrm{mmol} / 1 \mathrm{PMSF}, 1 \mathrm{mmol} / \mathrm{l}$ sodium azide, $\mathrm{pH}$ 7.4. Chromatography was run at $10 \mathrm{ml} / \mathrm{min}$ flow rate using the same solution for elution. One-ml fractions were collected and read at $280 \mathrm{~nm}(\bullet)$ for proteins, at $350 \mathrm{~nm}(\square)$ for browning products, and fluorescence $(\square)$ at Excitation $370 \mathrm{~nm}$ and Emission $440 \mathrm{~nm}$. The void volume, estimated as the exclusion volume for haemoglobin, was $19 \mathrm{ml}$. b Molecular weight standard plot. The BioGel column was calibrated with insulin $\left(\mathrm{M}_{\mathrm{r}}\right.$ $6000)$, bacitracin $\left(M_{r} 1400\right)$, riboflavin $\left(M_{r} 379\right)$ and glucose $\left(M_{\mathrm{r}}\right.$ 180). Peak $\mathrm{I}=3000 \mathrm{Da}$; Peak $\mathrm{II}=2100 \mathrm{Da}$; Peak III $=1500 \mathrm{Da} ;$ Peak IV $=700$. Over $90 \%$ of AGE fluorescence elutes in Peak I which displays an $M_{T}$ of $3 \mathrm{kDa}$. Most of the browned material also corresponds to this peak. It is noteworthy that some minor browned (Maillard reaction) peptides are not fluorescent

showed many coalescent particles as well as aggregation (Fig. $3 \mathrm{~b}$ ). AGE brown products remained attached to LDL even after extensive dialysis as shown in spectra displayed in Figure $3 \mathrm{c}-\mathrm{e}$.

Characterisation of antibodies. To carry out immunocytochemical follow-up of AGE-BSA and AGE-peptides on renal tissue we prepared suitable antibodies. Rabbits were immunised with extensively modified AGE-BSA and bled after the third booster. Antibodies to BSA epitopes were eliminated by two adsorp- a

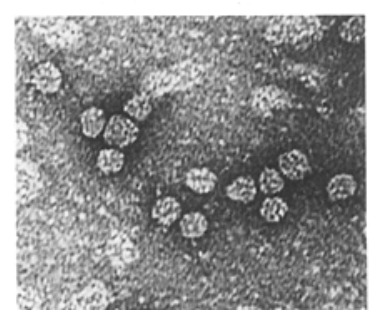

b

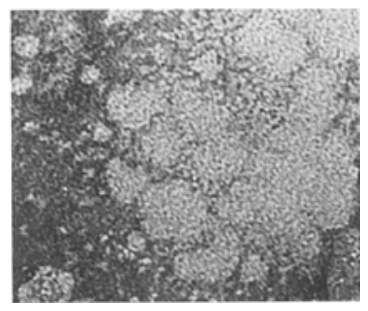

c

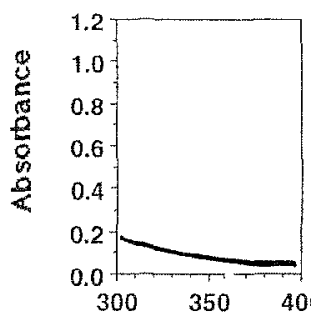

d

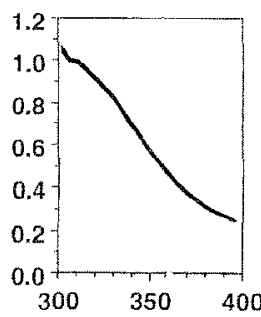

e

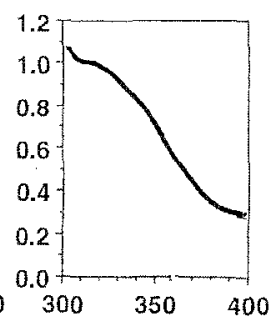

Wavelength, $\mathrm{nm}$

Fig.3.a-d Reaction of AGE-peptides with LDL. Human LDL $(d=1.051-1.163 \mathrm{mg} / \mathrm{ml})$ was incubated at $37^{\circ} \mathrm{C}$ for $16 \mathrm{~h}$ in the presence or absence of $3 \mathrm{mmol} / \mathrm{l}$ AGE-peptides in $10 \mathrm{mmol} / \mathrm{l}$ sodium phosphate, $140 \mathrm{mmol} / 1 \mathrm{NaCl}, 1 \mathrm{mmol} / \mathrm{l}$ EDTA, $1 \mathrm{mmol} / \mathrm{l} \mathrm{PMSF}$, and $1 \mathrm{mmol} / \mathrm{l}$ sodium azide. LDL was extensively dialysed and examined at the electron microscope by negative staining, and by spectrophotometry to detect attached AGE-peptides. Ultrastructural modifications (magnification $150000 \times$ ). a) LDL incubated in the absence of AGEpeptides. Typical monodispersed 20-nm LDL particles are apparent. b) LDL incubated in the presence of AGE-peptides. LDL particles appear coalescent. Reaction of AGE-peptides produced ultrastructural modifications of LDL particles which are not due to oxidation. Biochemical modifications: AGE products, the final result of the browning reaction display a characteristic absorption spectrum with maximum absorption at $350 \mathrm{~nm}$. Absorption spectra of: c) LDL incubated in the absence of AGE-peptides. No peak is apparent. d) LDL incubated in the presence of AGE-peptides. A 350-nm peak of absorption, corresponding to browning products is apparent. LDL had been extensively dialysed after incubation with AGE-peptides and prior to this measurement. This indicates that AGE-peptides were bound to LDL particles and that binding produces the modifications depicted in (b). e) AGEpeptides

tion steps on BSA. The anti-AGE antibodies obtained reacted with AGE epitopes regardless of the protein on which these adducts reside. This was apparent from the fact that our antibodies recognize AGE-BSA, AGE-Hb and AGE IgG but not BSA, $\mathrm{Hb}$ or IgG in dot immuno blotting and double immunodiffusion tests (Fig. 4a, b). AGE-peptides are also recognized (Fig. 4a). Reaction with AGE-BSA could be abolished by pre-incubation with AGE-BSA, $\mathrm{AGE}-\mathrm{Hb}$ or AGE IgG.

Cytochemical studies. In order to obtain further insight into the participation of different renal struc- 


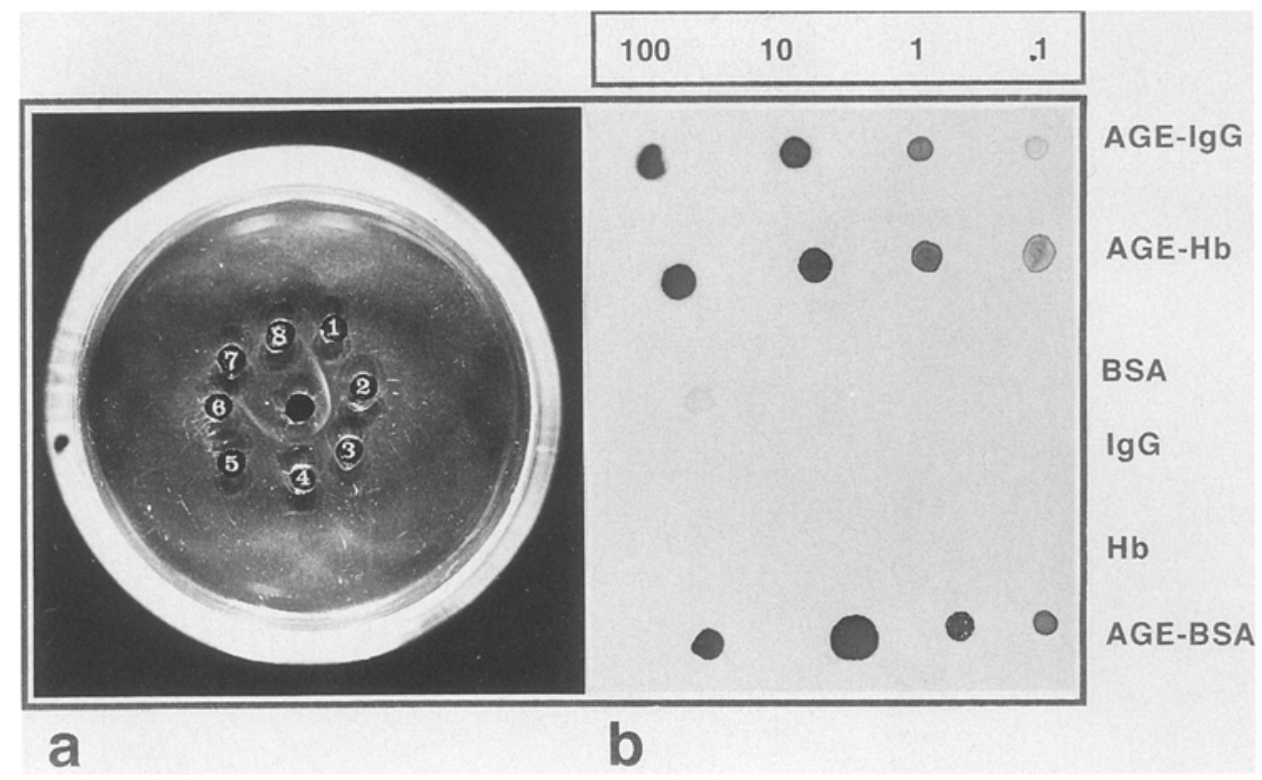

Fig. 4. Specificity of the AGE-antibody. The anti-AGE antibody generated in rabbits and purified as described in Methods was tested for specificity by double diffusion on agarose as well as by dot immunoblotting. The antibody not only recognises AGE adducts on AGE-BSA and AGE-peptides but on unrelated advanced glycated proteins such as AGE-Hb and AGE-IgG as well. No immunoreactivity towards the non glycated forms of these proteins is apparent. a) Double diffusion on agarose $(1 \%$ agarose in $50 \mathrm{mmol} / 1$ sodium barbital buffer, $\mathrm{pH}$ 8.6). The antibody ( $2 \mu \mathrm{l}$ of a solution containing $7.5 \mathrm{~g} / \mathrm{l}$ ) was placed in the central well. 1, AGE-IgG; 2, AGE-BSA; 3, AGE-Hb; 4, Hb; 5, AGE-peptides; 6, AGE-peptides; 7, BSA; 8, IgG. b) Dot immunoblotting. Figures on top indicate ng of protein in each dot. Each protein was spotted onto nitrocellulose membranes and dried. Membranes were then blocked for $2 \mathrm{~h}$, incubated at room temperature overnight with the antiAGE antibody diluted at 1:500 in non-fat dry milk. Blots were incubated with alkaline phosphatase-conjugated goat anti-rabbit IgG at 1:500 dilution in non-fat dry milk for $2 \mathrm{~h}$ before developing with a nitroblue tetrazolium substrate.

tures in the important clearance role of the kidney as regards the AGE-products and evidence the fate of AGE throughout the nephron we performed immunoelectron microscopy. AGE-BSA and AGE-peptides were prepared and injected into otherwise normal rats. Using colloidal gold post-embedding immunoelectron microscopy with our anti-AGE antibody we followed, in a short-term kinetic study, the cellular and subcellular localisation of circulating AGE throughout the nephron. AGE-peptides or AGEBSA $(10 \mathrm{mg} / \mathrm{animal})$ were injected i.v. into Sprague Dawley rats. After 15, 30 or 45 min of circulation, renal tissue was sampled and processed for protein Agold immunocytochemistry on thin tissue sections.

The distribution of AGE-BSA over the GBM is shown in Figure 5. When injected into normal rats most AGE-BSA was found in the lumen of capillary vessels and distributed along the endothelial side of the GBM. Presence of AGE-BSA in mesangial matrix was also apparent. A similar pattern was observed for all the time points studied, 15,30 or $45 \mathrm{~min}$ (Fig. 5a, b and c, respectively). This suggests that, due to the size of AGE-BSA, during this period no significant elimination of AGE-BSA from the circulation by filtration takes place. A quantitative evaluation of the distribution of AGE-BSA on the glomerular wall confirmed its preferential location along the endothelial side of the GBM (Fig. 6).

A short-term follow-up of AGE-peptide localisation at the kidney level has shown that they are easily filtered and are actively reabsorbed by the proximal convoluted tubule. At $15 \mathrm{~min}$, little labelling was found in the glomerular wall (Fig. 7). Instead, the labelling was present in the urinary space and associated with proximal microvilli of epithelial cells (Fig. 8a). Early and late endosomes of these proximal tubular cells also display significant labelling. At $30 \mathrm{~min}$ (Fig. $8 \mathrm{~b}$ ) and $45 \mathrm{~min}$ (Fig. $8 \mathrm{c}$ ), lysosomes added to the pattern of labelling. The distal tubules were devoid of labelling in any of the intervals studied. Other cellular structures such as mitochondria and nuclei showed few gold particles. These are considered as background staining in view of the results obtained using pre-adsorbed antibodies. These observations point to participation of the endo-lysosomal apparatus of the proximal convoluted tubule in the disposal of AGE-peptides.

Cytochemical controls. All the labelling observed with the application of the anti-AGE-BSA antibody was specifically and significantly reduced by pre-incubation of the antibody with an excess of AGEBSA but not with BSA (data not illustrated). 


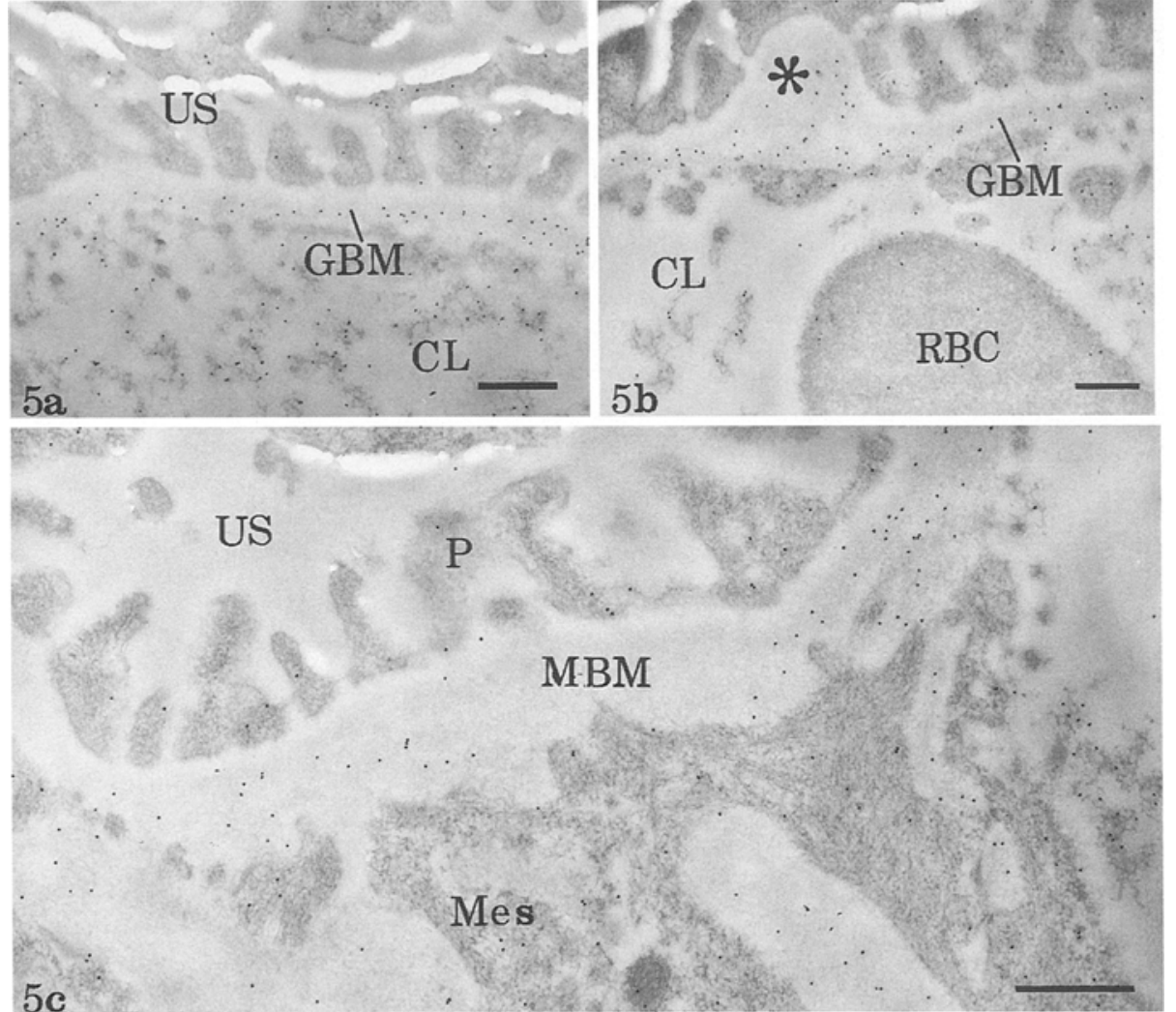

Fig. 5. a-c Localisation of injected AGE-BSA on the glomerular wall of rat kidney. Renal tissue sections from normal rats, injected with $10 \mathrm{mg}$ of AGE-BSA. The probe was injected into the inferior vena cava and the animals were killed after 15 (a:), 30 (b:) or 45 (c:) min. The labelling by gold particles is distributed in the capillary lumen (CL), over the endothelial side of the glomerular basement membrane $(\mathrm{GBM})$ and in the mesangium (MBM). The distribution was similar for all the time points studied. The urinary space (US) appears almost free of labelling. * focal accumulation of basement membrane labelled for AGE-BSA; Mes, mesangial cell; $P$, podocytes. Bars $=0.5 \mu \mathrm{m}$

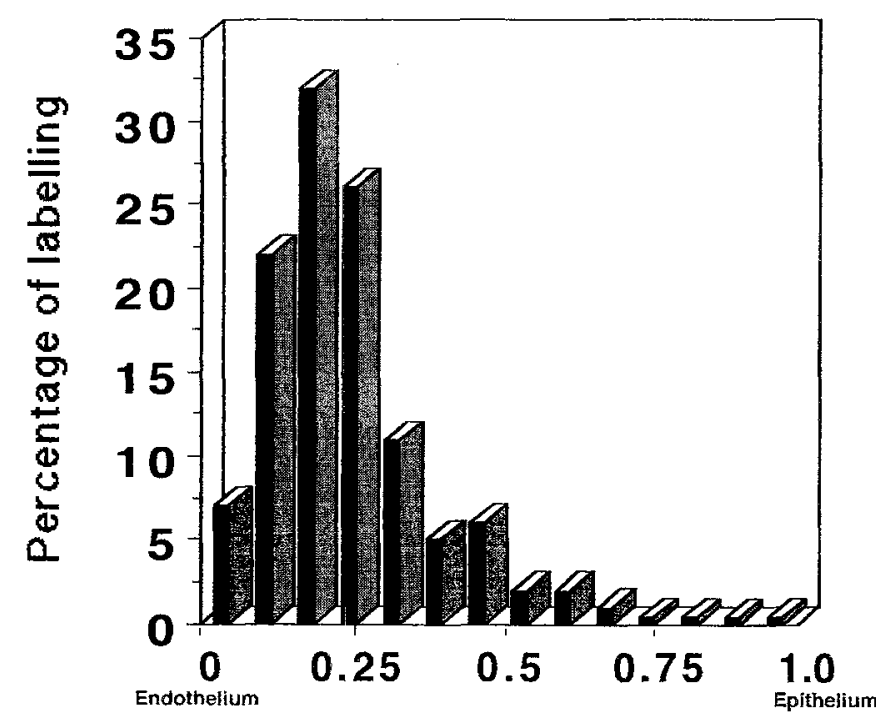

Fig. 6. Histogram of the distribution of AGE-BSA on the glomerular basement membrane. Renal tissue sections from normal rats, injected with $10 \mathrm{mg}$ of AGE-BSA and killed $30 \mathrm{~min}$ later. The quantitative evaluation of the distribution of the labelling is expressed as the ratio: distance endothelium-gold particle/distance endothelium-epithelium, (resulting in values between 0 and 1). For each animal 10 microscopic fields were recorded on video at $\times 31,000$ magnification and brought to a final magnification of $\times 105,000$. A peak of distribution of the labelling at the endothelial side of the GBM shows the retention of AGE-BSA at this site.

\section{Discussion}

In the past few years several reports indicate that low molecular weight AGE-peptides accumulate in the blood of patients with kidney failure or diabetes mellitus $[15,32,34,36,40]$. These tissue-derived degradation products may be produced either by a specific macrophage AGE-receptor pathway [26] or by extracellular proteolytic systems. These are extremely reactive substances capable of modifying circulating or tissue proteins. LDL, for instance contains a fraction bearing AGE adducts, AGE-LDL. Given its short half-life it was difficult to conceive that this modification could be mediated by glucose. Instead, it has been demonstrated that AGE-peptides, both synthetic and extracted from patients, readily bind to LDL altering its metabolism [31]. Through this kind of evidence it is becoming clear that AGE-peptides are responsible for the modification of circulating and tissue resident proteins, leading to structural and functional changes. Thus, probably some molecular modifications previously attributed to glucose itself might be due to circulating AGE-peptides. More important, these peptides are active even when euglycaemia is achieved, so they are capable of perpetuating the hyperglycaemic insult through what becomes a vicious cycle. An effective clearance mechanism must be operative in the normal situation. Several lines of evidence show that AGE-peptides are eliminated by the kidney $[34-36,39,41,58]$. They increase 


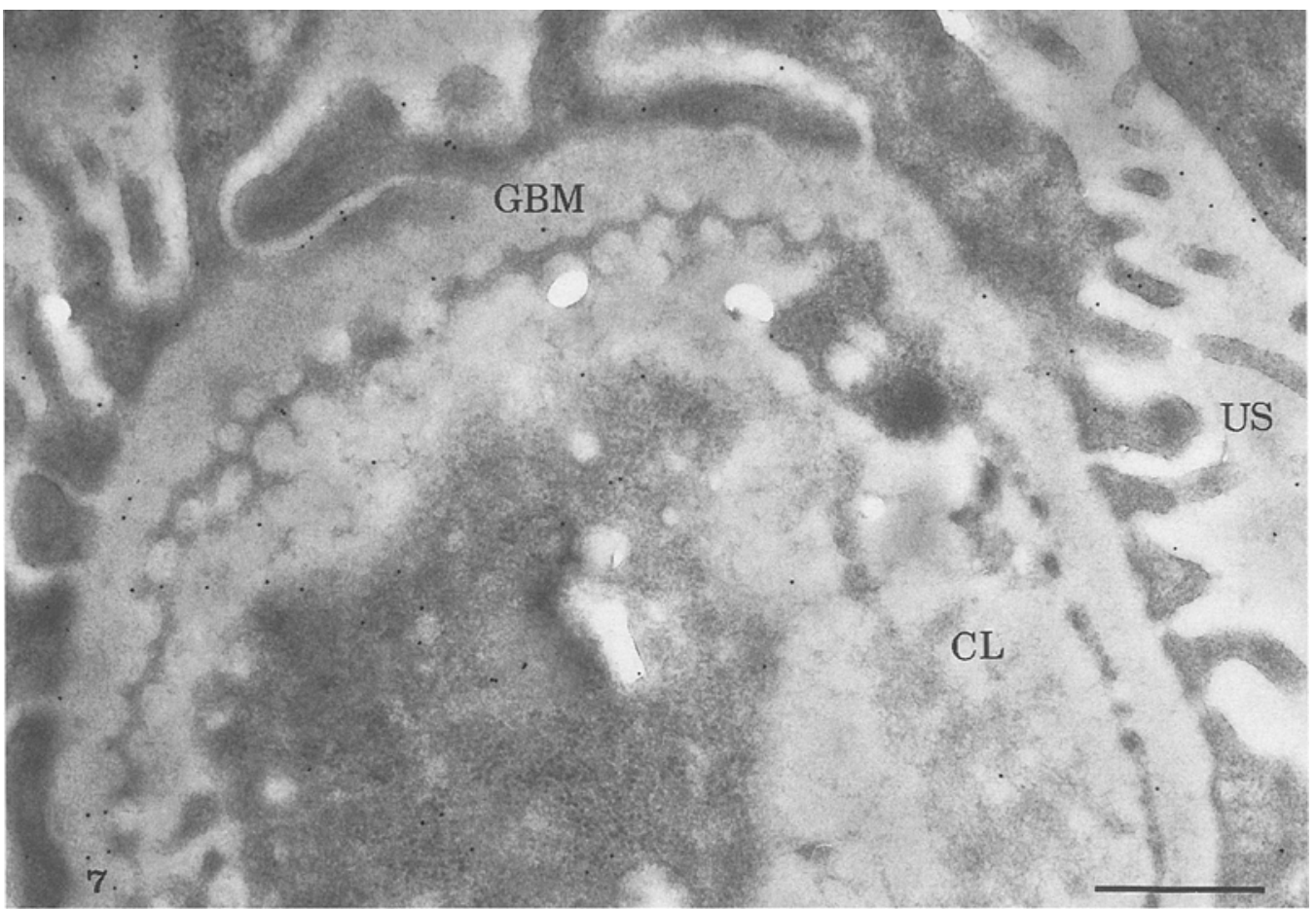

Fig.7. Localisation of injected AGE-peptides on the glomerulus of rat kidney. Renal tissue sections from a normal rat, injeced with $10 \mathrm{mg}$ of AGE-peptides. The probe was injected into the inferior vena cava and the animal was killed 15 min later. The labelling by gold particles is distributed in the capillary lumen (CL) and in the urinary space (US). Little labelling is associated with the glomerular basement membrane (GBM). $\mathrm{Bar}=0.5 \mu \mathrm{m}$

in renal failure even in the absence of diabetes, and up to sixfold in diabetic patients with renal impairment $[34,36]$. They are only partly removed by dialysis and regain predialysis levels as soon as $3 \mathrm{~h}$ after the dialysis procedure. The superior survival rate of diabetic kidney transplant recipients suggests an additional benefit linked to the graft. One of the substances known to be better cleared by the kidney than by dialysis are circulating AGE-peptides [33]; they may account in part for the poor prognosis of diabetic patients with end-stage renal disease.

This study was designed to reveal the renal fate of AGE. We used AGE-BSA as a model AGE protein since it has been employed in multiple studies looking for the effects generated by AGE. Bucala et al. $[8,12]$ have demonstrated that AGE-BSA quenches nitric oxide and that formation of AGE-products in diabetic rats correlates with impaired vasodilatation, a characteristic feature of diabetes. Using a similar model $\left({ }^{125} \mathrm{I}\right.$-AGE- rabbit albumin and ${ }^{125} \mathrm{I}$-AGE-rat albumin with detection in homogenates), Vlassara et al. [16] have demonstrated that AGE injected into otherwise healthy animals led to tissue accumulation and to changes in vascular tone paralleling those seen in diabetes. Using AGE-BSA tagged with colloidal gold particles, we have recently demonstrated the intrinsic reactivity of these adducts towards renal tissue structures [38]. AGE-BSA and AGE-peptides were then prepared in conditions previously reported and the fate of injected AGE-products in renal tissue of control rats was monitored by colloidal gold post-embedding immunoelectron microscopy.

Antibodies against AGE were prepared by injecting strongly modified AGE-BSA to rabbits. Antibodies to epitopes present both in BSA and in AGEBSA were eliminated by a two-step adsorption with BSA. IgG was next purified by ammonium sulphate precipitation and DEAE chromatography. In keeping with previous results from other groups, these antibodies recognize AGE epitopes in several proteins but not in their non-glycated counterparts. In our case, they react with AGE-BSA, AGE-Hb and AGE-IgG but not against BSA, Hb and IgG. Furthermore, they are able to recognize epitopes on AGE-peptides.

Our short-term study on the renal handling of intact AGE-BSA showed a particular disposition of molecules along the endothelial side of the GBM. As reported previously [57], this reflects molecules effectively retained by the size and charge exclusion barrier of the GBM and not necessarily bound particles. However, our previous results [38], showing binding of AGE-BSA-gold but not BSA-gold to GBM, suggest that at least one portion of these molecules is effectively bound to GBM components. In fact, the combination of physical contact favoured by the intense haemodynamic pressure, linked to the extreme reactivity of AGE moieties should provide a particularly effective synergism for this binding. In 

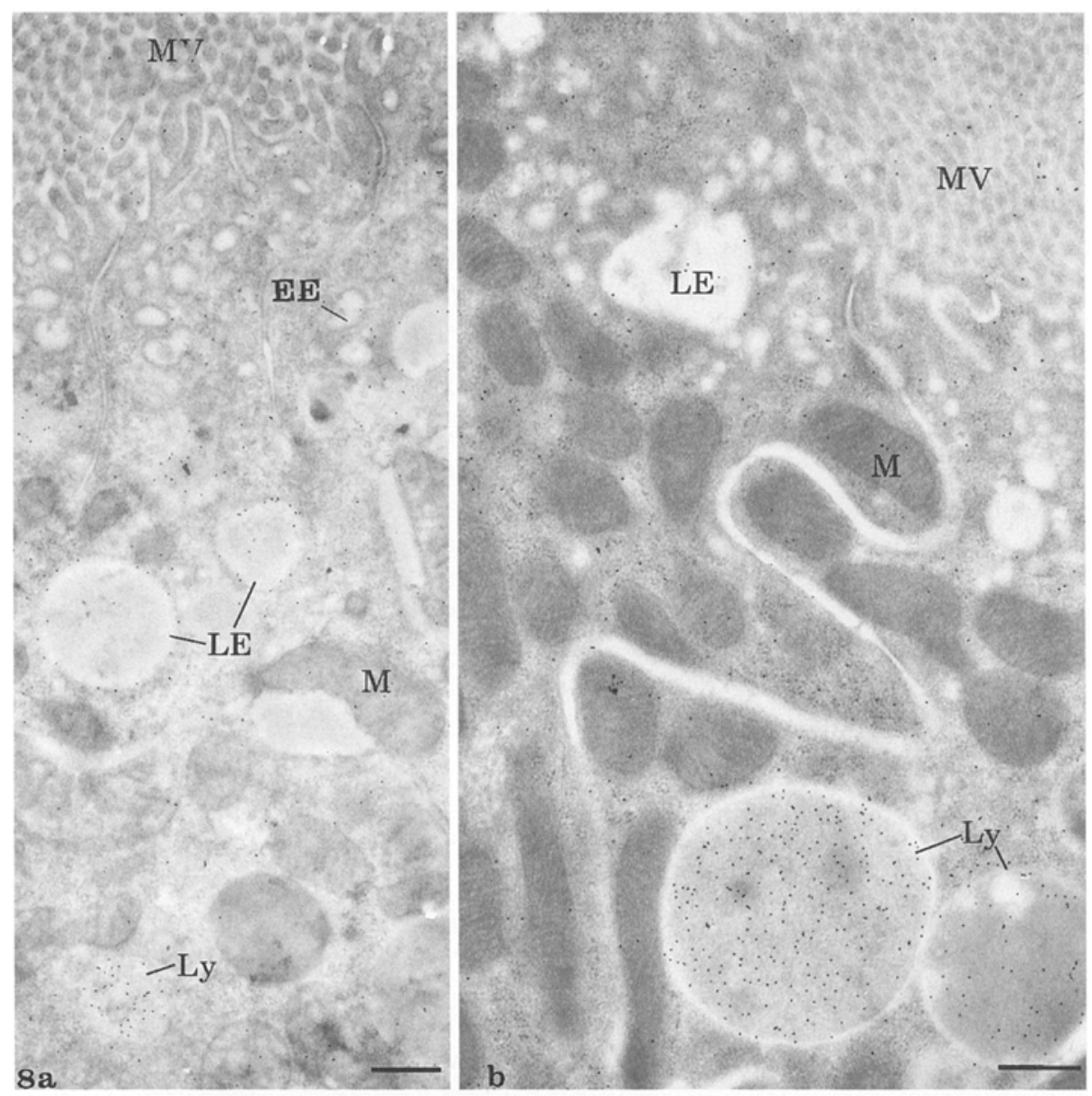

Fig. 8a-c. Localisation of injected AGE-peptides on the proximal tubular epithelial cells of rat kidney. AGEpeptides were filtered by the glomeruli, reabsorbed and metabolised by the endo-lysosomal system of proximal convoluted tubular cells. Renal tissue sections from normal rats, injected with $10 \mathrm{mg}$ of AGE-peptides. The probe was injected into the inferior vena cava and the animals were killed 15 (a), 30 (b) or 45 (c) min later. At 15 min (a) the labelling was present in the urinary space (US) and associated with microvilli of proximal epithelial cells (MV). Early (EE) and late endosomes (LE) of these proximal tubular cells display intense labelling as well. At $30(\mathbf{b})$ and $45(\mathbf{c})$ min, lysosomes (Ly) added to the pattern of labelling. Other cellular structures such as mitochondria and nuclei show few gold particles. Bars $=0.5 \mu \mathrm{m}$

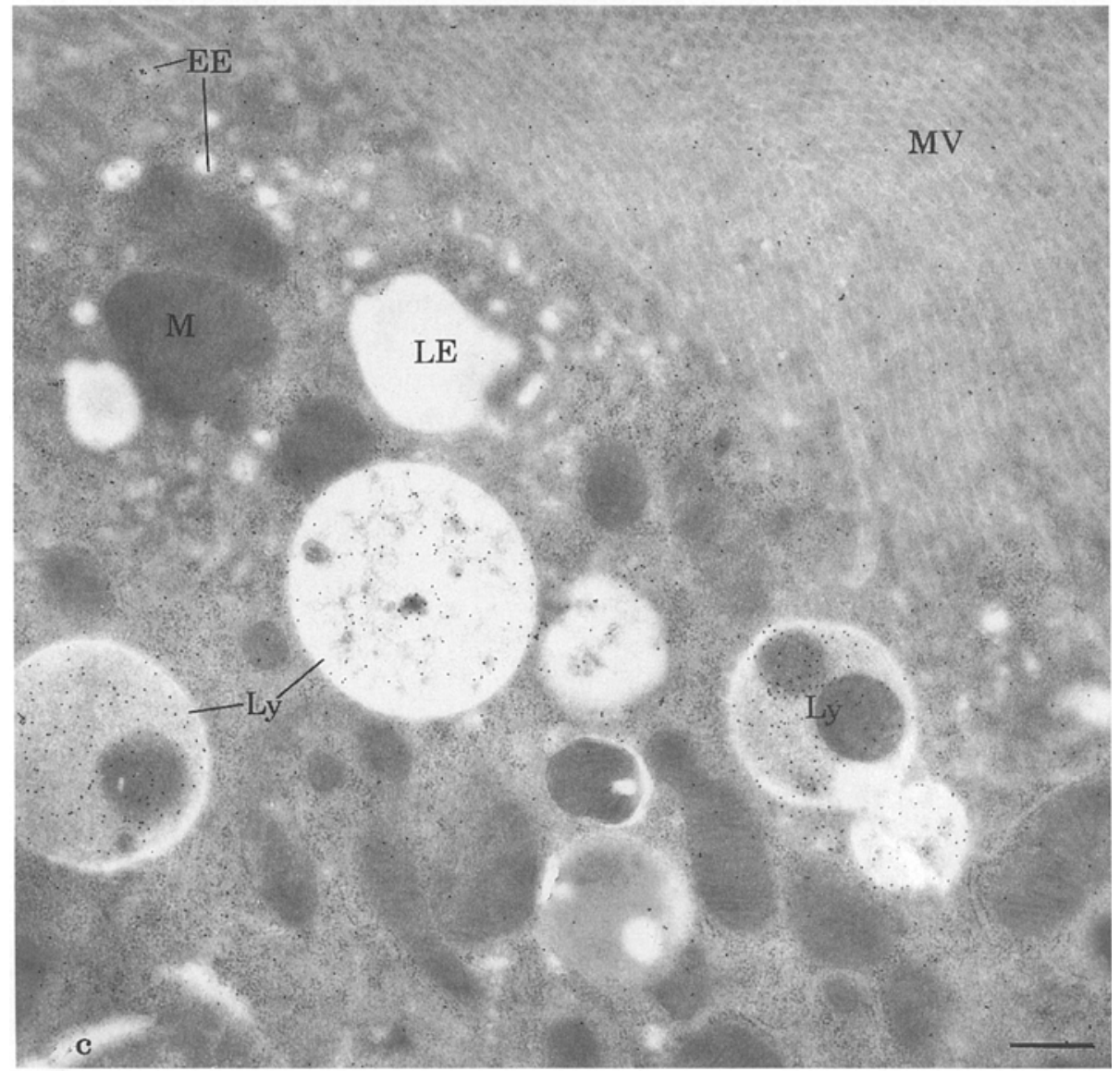


keeping with this reasoning, recent results from Vlassara et al. [39] clearly demonstrate that chronic injection of AGE albumin into rats reproduces glomerular changes seen in glomerulosclerosis. Changes seen on these chronic administration experiments could be due not only to the direct cross-linking effect of AGE but to receptor-mediated cytokine effects as well.

The participation of these phenomena on the multifactorial pathogenesis of diabetic glomerulopathy is strongly suggested by these studies.

In this regard, we performed experiments to ascertain the renal handling of AGE-peptides. The AGEpeptides generated displayed the characteristics shown previously. Their $\mathrm{M}_{\mathrm{r}}$ was about $3 \mathrm{kDa}$ (about 30 amino acid residues) as shown by gel filtration chromatography and they exhibited the characteristic fluorescence and absorption spectra. These properties of our AGE-peptides closely resemble those reported for AGE-peptides isolated from plasma of diabetic and kidney failure patients $[15,32,34,36]$. To test the reactivity of AGE-peptides in vitro, they were incubated in the presence of LDL. They proved to be extremely reactive towards LDL, producing similar changes as those recently reported for the interaction between AGE-BSA and LDL [31, 59]. Moreover, AGE-peptides seem to be somewhat more aggressive than AGE-BSA. The ultrastructural changes illustrated here were produced after $16 \mathrm{~h}$ incubation under strict non-oxidative conditions, while similar modifications with AGE-BSA needed concomitant incubation with copper ions as oxidants [59].

When injected into normal rats, a short-term follow-up of their localisation at the kidney level has shown that they are easily filtered and actively reabsorbed by the proximal convoluted tubule. At $15 \mathrm{~min}$ the labelling was found in the urinary space and on the microvilli. Endocytosis by the proximal tubular epithelial cells takes place as witnessed by the labelling of endocytic vesicles as well as early and late endosomal compartments. Further steps on the endocytic pathway are apparent at 30 and $45 \mathrm{~min}$, when the labelling appeared to be particularly intense in late endosomes, while labelled lysosomes become predominant. Our data point to a participation of the endo-lysosomal apparatus of the proximal convoluted tubule to the disposal of AGE-peptides. We interpret these data in the light of recently reported values of AGE-peptide clearance in humans and rats $[15,39]$. This clearance, being lower than the creatinine clearance, indicates that not all of circulating AGE-peptides are filtered; some process of reabsorption occurs. It is possible that both events take place simultaneously. The labelling we show here in the urinary space strongly suggests a very effective filtration. On the other hand, labelling of endosomal compartments reflects a great reabsorption process at the level of the proximal convoluted tubule and strongly suggests that this is the predominant elimination mechanism.

Reabsorption could represent an AGE-receptormediated mechanism since receptors for AGE adducts have been described in several cell types such as macrophages, endothelial and mesangial cells [19$21,23,29,58]$. Activation of these receptors triggers several cell responses including cytokine secretion and oxidation-enhancing reactions [7]. Following this reasoning, one might speculate that in diabetes, an increase in these processes could participate in the interstitial fibrosis reaction accompanying the characteristic glomerulosclerosis of end-stage renal disease. The final fate of AGE-peptides also remains to be determined since no mammalian enzyme has been discovered that could mediate the catabolism of AGE moieties once the lysosomal hydrolysis of peptide bonds has taken place. A slow secretory process of resulting AGE amino acids into urine could be suggested and could also account for the presence of AGE adducts such as pentosidine in the urine of diabetic patients [60]. In the long run, the increased tubular charge of AGE-peptides due to diabetes may overwhelm the whole process and lead to tubular disorders.

Finally, another feature of AGE-peptides is the ability to bind covalently to phospholipids as described previously [31]. It is reasonable to think that AGE-peptides react with membrane phospholipids if present in high local concentrations such as those shown here in lysosomes and if sufficient time is allowed. An accumulation of these adducts in tubular lysosomes might prove to be one further aggression to membranes and yet another process contributing to the overall toxicity.

In conclusion, our study confirms the key role played by the kidney in regard to AGE catabolism, gives ultrastructural evidence for the GBM and mesangial accumulation of AGE-BSA and demonstrates the important participation of resorption processes at the level of the proximal tubules in the clearance of circulating AGE-peptides.

Acknowledgements. We are grateful to Ms. D. Gingras, J. Godbout, G. Mayer and J. Leveillé for their excellent technical assistance. This work was supported by the Medical Research Council of Canada and the Association du Diabète du Québec.

\section{References}

1. Nathan D (1994) Relation between metabolic control and long-term complications of diabetes. In: Kahn CR (ed) Joslin's Diabetes Lea and Febiger, Philadelphia

2. Dahl-Jorgensen K, Brinchmann-Hansen O, Bangstad HJ, Hanssen KF (1994) Blood glucose control and microvascular complications - what do we do now? Diabetologia 37 : 1172-1177

3. The Diabetes Control and Complications Trial Data Group (1993) The effect of intensive treatment of diabetes on the 
development and progression of long-term complications in insulin dependent diabetes mellitus. N Engl J Med 329: 977-986

4. Monnier VM, Cerami A (1981) Nonenzymatic browning in vivo: possible process for aging of long-lived proteins. Science 211: 491-494

5. Brownlee M, Cerami A (1981) The biochemistry of the complications of diabetes mellitus. Annu Rev Biochem 50: 385-432

6. Brownlee M (1994) Glycation and diabetic complications. Diabetes 43: 836-841

7. Vlassara H, Bucala R, Striker L (1994) Pathogenic effects of advanced glycosylation: biochemical, biologic, and clinical implications for diabetes and aging. Lab Invest 70: $138-151$

8. Bucala R, Cerami A (1992) Advanced glycosylation: chemistry, biology and implications for diabetes and aging. $\mathrm{Adv}$ Pharmacol 23: 1-19

9. Brownlee M, Vlassara H, Cerami A. (1987) The pathogenetic role of nonenzymatic glycosylation in diabetic complications. In: MJC Crabbe (ed) Diabetic complications: scientific and clinical aspects. Churchill Livingston, London $\mathrm{p} 94$

10. Brownlee M, Cerami A, Vlassara H (1988) Advanced glycosylation end-products in tissue and the biochemical basis of diabetic complications. N Engl J Med 318: 1315-1321

11. Brownlee M (1990) Advanced products of non-enzymatic glycosylation and the pathogenesis of diabetic complications. In: Rifkin H, Porte D Jr (eds) Diabetes mellitus: theory and practice. Elsevier, New York, pp 279-291

12. Bucala R, Tracey KJ, Cerami A (1991) Advanced glycosylation products quench nitric oxide and mediate defective endothelium-dependent vasodilation in experimental diabetes. J Clin Invest 87: 432-438

13. Bucala R, Model P, Cerami A (1984) Modification of DNA by reducing sugars: a possible mechanism for nucleic acid aging and age-related dysfunction in gene expression. Proc Natl Acad Sci USA 81: 105-109

14. Bucala R, Vlassara H, Cerami A (1992) Advanced glycosylation end-products. In: Harding JJ Crabbe, MJC (ed) Posttranslational modifications of proteins, vol 2. CRC Press Inc, Boca Raton, pp 53-179

15. Makita Z, Bucala R, Rayfield EJ et al. (1994) Reactive glycosylation end products in diabetic uraemia and treatment of renal failure. Lancet 343: 1519-1522

16. Vlassara H, Fuh H, Makita Z, Krungkrai, Cerami A, Bucala R (1992) Exogenous advanced glycosylation endproducts induce complex vascular dysfunction in normal animals: a model for diabetic and aging complications. Proc Natl Acad Sci USA 89: 12043-12047

17. Makita Z, Vlassara H, Rayfield E et al. (1992) Hemoglobin- AGE: a circulating marker for advanced glycosylation. Science 258: 651-653

18. Makita Z, Radoff S, Rayfield EJ et al. (1991) Advanced glycosylation end products in patients with diabetic nephropathy. New Engl J Med 325: 836-842

19. Schmidt AM, Mora R, Cao K et al. (1994) The endothelial cell binding site for advanced glycation end products consists of a complex: an integral membrane protein and a lactoferrin-like polypeptide. J Biol Chem 269: 9882-9888

20. Schmidt AM, Vianna M, Gerlach J et al. (1992) Isolation and characterization of two binding proteins for advanced glycation end products from bovine lung which are present on the endothelial cell surface. J Biol Chem 267: 1498714997

21. Schmidt AM, Hori O, Brett J, Yan SD, Wautier JL, Stern D (1994) Cellular receptors for advanced glycation end pro- ducts. Implications for induction of oxidant stress and cellular dysfunction in the pathogenesis of vascular lesions. Arteriosclerosis and Thrombosis 14: 1521-1528

22. Doi T, Vlassara H, Kirstein M, Yamada Y, Striker GE, Striker LJ (1992) Receptor specific increase in extracellular matrix production in mouse mesangial cells by advanced glycation end products is mediated via platelet derived growth factor. Proc Natl Acad Sci USA 89: 2873-2877

23. Horii Y, Skolnik E, Suthanthiran M, Vlassara H (1992) Novel T-cell receptors for advanced glycation endproducts (AGE) mediate production of IFN. Diabetes 41: 59A (Abstract)

24. Neper M, Schmidt AM, Brett J et al. (1992) Cloning and expression of RAGE: a cell surface receptor for advanced glycation end products of proteins. J Biol Chem 267: $14998-15004$

25. Vlassara H, Moldawer L, Chan B (1989) Macrophage/ monocyte receptor for nonenzymatically glycosylated proteins is up-regulated by cachectin/tumor necrosis factor. $J$ Clin Invest 84: 1813-1820

26. Vlassara H, Brownlee M, Cerami A (1988) Specific macrophage receptor activity for advanced glycosylation endproducts inversely correlates with insulin levels in vivo. Diabetes $37:$ :56-461

27. Radoff S, Vlassara H, Cerami A (1988) Characterization of a solubilized cell surface binding protein on macrophages specific for protein modified nonenzymatically by advanced glycosylation endproducts. Arch Biochem Biophys 263: 418-423

28. Vlassara H, Brownlee M, Cerami A (1986) Novel macrophage receptor for glucose-modified protein is distinct from previously described scavenger receptors. J Exp Med 164: 1301-1309

29. Yan SD, Schmidt AM, Anderson GM et al. (1994) Enhanced cellular oxidant stress by the interaction of advanced glycation end products with their receptors/binding proteins. J Biol Chem 269: 9889-9897

30. Wautier JL, Wautier MP, Schmidt AM et al. (1994) Advanced glycation end products (AGEs) on the surface of diabetic erythrocytes bind to the vessel wall via a specific receptor inducing oxidant stress in the vasculature: a link between surface associated AGEs and diabetic complications. Proc Natl Acad Sci USA 91: 7742-7746

31. Bucala R, Makita Z, Vega G et al. (1994) Modification of low density lipoprotein by advanced glycation end products contributes to the dislipidemia of diabetes and renal insufficiency. Proc Natl Acad Sci USA 91: 9441-9445

32. Deppisch R, Nawroth P (1994) Toxicity of uraemia-does it come of AGE? Nephrol Dial Transplant 9: 1-2

33. Makita Z, Radoff S, Rayfield EJ, Yang, Z (1991) Clinical assessment and significance of advanced glycation in patients with diabetic nephropathy. New Engl J Med 325: 836-842

34. Papanastasiou P, Grass L, Rodela H, Patrikarea A, Oreopoulos D, Diamandis EP (1994) Immunological quantification of advanced glycation end products in the serum of patients on hemodialysis or CAPD. Kidney Int 46: 216-222

35. Mitsuhashi T, Nakayama H, Itch T et al. (1993) Immunochemical detection of advanced glycation end products in renal cortex from streptozotocin-induced diabetic rats. Diabetes 42: 826-833

36. Kobert SM, Makita Z, Firanek CA, Vlassara H (1993) Advanced glycation end products in continuous ambulatory peritoneal dialysis patients. A J Kidney Dis 22: 588-591

37. Horiuchi S, Araki N, Morino Y (1991) Immunochemical approach to characterize advanced glycation end products of the Maillard reaction: evidence for the presence of a common structure. J Biol Chem 266: 7329-7332 
38. Gugliucci A, Bendayan M (1995) Reaction of advanced glycation products with renal tissue from normal and streptozotocin-induced diabetic rats. An ultrastructural study using colloidal gold cytochemistry. J Histochem Cytochem 43: 591-600

39. Vlassara H, Striker LJ, Teichberg S, Fuh H, Ming LY, Steffes M (1994) Advanced glycation end products induce glomerular sclerosis and albuminuria in normal rats. Proc Natl Acad Sci USA 91: 11704-11708

40. Sell DR, Monnier VM (1990) End-stage renal disease and diabetes catalyze the formation of a pentose-derived crosslink from aging human collagen. J Clin Invest 85(2):380384

41. Fuh H, Yang D, Striker L, Striker G, Vlassara H (1992) In vivoAGE-peptide injection induces kidney enlargement and glomerular hypertrophy in rabbits: prevention by aminoguanidine. Diabetes 41[Suppl]:9A (Abstract)

42. Njoroge FG, Sayre LM, Monnier VM (1987) Detection of D- glucose derived pyrrole compounds during Maillard reaction under physiological conditions. Carbohyd Res 167: 211

43. Hayase F, Nagaraj RH, Miyata S, Njoroge FG, Monnier VM (1989) Aging of proteins: immunological detection of a glucose derived pyrrole formed during Maillard reaction in vivo. $\mathrm{J}$ Biol Chem 264: 3758-3764

44. Njoroge FG, Monnier VM (1989) The chemistry of the Maillard reaction under physiological conditions: a review. Prog Clin Biol Res 304: 85-91

45. Steinbrecher UP (1987) Oxidation of human low density lipoprotein results in derivatization of lysine residues of apolipoprotein B by lipid peroxide decomposition products. J Biol Chem 262: 3603--3610

46. Laemmli UK (1970) Cleavage of stuctural proteins during assembly of the head of bacteriophage T4. Nature 227 : 680-685

47. Bjerrum OJ, Schafer-Nielsen C (1986) In: Dun MJ (ed) Analytical electrophoresis. Chemie, Weinheim, p 315

48. Hammes BD (1981) An introduction to polyacrylamide gel electrophoresis. In: Hammes BD, Rickwood D (eds) Gel electrophoresis of proteins: a practical approach. IRL Press Ltd, London, pp 1-19
49. Schumaker VN, Puppione D (1986) Sequential flotation ultracentrifugation. Methods Enzymol 128: 155-170

50. Forte TM, Nordhausen RW (1986) Electron microscopy of negatively stained lipoproteins. Methods Enzymol 128: 442-457

51. Nakayama H, Taneda S, Kuwajima S et al. (1989) Production and characterisation of antibodies to advanced glycation products on proteins. Biochem Biophys Res Commun 162: 740-747

52. Makita Z, Vlassara H, Cerami A, Bucala R (1992) Immunochemical detection of advanced glycation end products in vivo. J Biol Chem 267: 5133-5138

53. Harlow E, Lane D (1988) Immunization. In: Harlow E, Lane D (ed) Antibodies: a laboratory manual. Cold Spring Harbor Laboratory, New York, pp 53-137

54. Harlow E, Lane D (1988) Purification and storage of antibodies. In: Harlow E, Lane D (ed) Antibodies: a laboratory manual. Cold Spring Harbor Laboratory, New York, pp 283-318

55. Smith P, Krohn R, Hermanson G et al. (1985) Measurement of protein using bicinconinic acid. Anal Biochem 150: $76-85$

56. Bendayan M (1984) Protein A-gold electron microscopic immunocytochemistry: methods, applications and limitations. J Elec Micros Tec 1: 243-270

57. Bendayan M, Gingras D, Charest P (1986) Distribution of endogenous albumin in the glomerular wall of streptozotocin-induced diabetic rats. Diabetologia 29: 868-875

58. Skolnik EY, Yang Z, Makita Z, Radoff S, Kirstein M, Vlassara H (1991) Human and rat mesangial cell receptors for glucose-modified proteins: potential role in kidney tissue remodeling and diabetic nephropathy. J Exp Med 174: 931-939

59. Dobrian A, Simionescu M (1995) Irreversibly glycated albumin alters the physico-chemical characteristics of low density lipoproteins of normal and diabetic subjects. Biochim Biophys Acta 1270: 26-35

60. Takahashi M, Ohishi T, Aoshima $H$ et al. (1993) The Maillard protein cross-link pentosidine in urine from diabetic patients. Diabetologia 36: 664-667 